\title{
Transfection of Gametes: A Method to Generate Transgenic Animals
}

\author{
Transfección de Gametos: Un Método para Generar Animales Transgénicos \\ Pedro Esponda
}

\begin{abstract}
ESPONDA, P. Transfection of gametes. A method to generate transgenic animals. Int. J. Morphol., 23(3):281-284, 2005.
SUMMARY: The production of transgenic animals (TA) using transfected spermatozoa or eggs is commented. Different methods have been employed to introduce transgenes into the gametes of several vertebrates and invertebrates. Methods for the transfection of gametes have employed naked DNA, viral vectors, DNA/Liposome complexes, electroporation or high velocity microprojectiles. Spermatozoa and oocytes or eggs have showed a good transfection efficience ( $80 \%$ in some cases), and microscopical observations demonstrated that the transgenes appeared localized in the nucleus. Gametes have shown to be naturally protected against the entrance of foreign genes because some semino plasma or plasma membrane proteins block the entrance of foreign genes in spermatozoa. In the female this blockage is undertaken by the egg covers (the zona pellucida in mammals and the perivitelline coat in mollusks). In several cases the production of TA has been described after using the transfected gametes for in vitro fertilization or inseminations. Sometimes, larger percentages of TA were observed ( $85 \%$ in salmon). Nevertheless, these TA were mainly chimeric for the transgene and they were not capable to establish transgenic lines. It seems probable that TA produced by gamete transfections are different from those originated by the conventional microinjection procedures. Furthermore, gametes would develop some kind of mechanisms that modify the integration/ expression of transgenes, or that block the integration of transgenes in the germinal line.
\end{abstract}

Key words: Eggs; Oocyte; Spermatozoa; Transfection; Transgenic animals.

Transfection methods. The first transfection procedures occurred in the early 1960 s and experiments with different cell types and tissues has now become widespread (Wolff \& Lederberg, 1994). Different transfection methods have been employed (Mulligan, 1993): a) The in vitro procedure when foreign genes are introduced into cultured cells or tissues. b) The in vivo method, when genes are directly introduced into the tissue (by injection, aerosol, etc); c) The ex-vivo system, in which cells are transfected in vitro and then introduced into a living organism; b and c) Have been the basis for human gene therapies (Anderson, 1998).

The foreign DNA can be used free or associated to different vectors (Mulligan). Vectors are molecules that become associated to DNA and facilitate its entrance into the host cytoplasm and nuclei. The most employed vectors are some viruses (retrovirus or adenovirus), some lipidic molecules and liposomes. On the other hand, DNA has been also employed as a free molecule (naked DNA).

History of gamete transfection. The first experiment devoted to transfect the male gamete was done in the rabbit by Brackett et al. (1971). In 1989, the transfection of the sea urchin spermatozoa was demonstrated by Arezzo (1989) and the same year an interesting paper showed the production of transgenic mice after employing transfected spermatozoa (Lavitrano et al. 1989). From then several laboratories used this in vitro procedure in different invertebrates (sea urchin, bee, fly, abalone, silk-worm and mussels) and vertebrates (mouse, rabbit, pig, bull) (Spadafora, 1998). In 1998, sperm transfection was developed in vivo using gene injections into the vas deferens of the mouse (Huget \& Esponda, 1998). On the other hand, Perry et. al. (1999) employed a particular procedure in which death and damaged (freeze-thawed or exposed to detergents) spermatozoa were transfected and then microinjected into oocytes. Using this procedure a large percentage of transgenics was produced (Perry et al.).

In comparison to spermatozoon transfection, the female gamete has been scarcely analyzed. Mouse oocytes and early embryos have been transfected using recombinant adenovirus or DNA/cationic liposome complexes (Carballada et al., 2000; Tsukui et al., 1995; Tsukui et al., 1996) as vectors. Furthermore, transgenic monkeys were produced using oocytes transfected 
with retrovirus as gene vectors (Chan et al., 2001). Recently, Laurema et al. (2003) showed that rabbit oocytes can be transfected after a direct injection of the foreign DNA (associated to adenovirus or liposomes) into the uterine arteries. Fish and chicken embryos were also transfected using lipofection, electroporation or high velocity microprojectiles (Szelei et al., 1994; Powers et al., 1992; Zelenin et al. 1991). In the case of invertebrates, early embryos of a surf-clam were successfully transfected using retroviral vectors ( $\mathrm{Lu}$ et al., 1996), and sea urchin eggs by the employ of a particle gun method (Akasaka et al., 1995).

Procedures and results of gamete transfection. The usual procedure to transfect the spermatozoon has been the in vitro method. Gametes are incubated during short time periods in a solution containing the gene constructions and then they are checked for transfection, used for inseminations or for in vitro fertilization procedures (Spadafora). In several cases naked DNA was employed successfully, but DNA-Liposome complexes or electroporation procedures have been also used (Spadafora). The in vivo method employed a transgene injection into the vas deferens of the mouse and after 6-12 hours the gametes were collected and analyzed (Huget \& Esponda). In the case of the female gamete in vitro transfections using liposomes or retroviruses have been applied successfully. As well as, electroporation, high velocity microprojectiles or particle gun methods have been also employed (see previous paragraph).

The localization of the foreign gene in spermatozoa has been done using fluorescent in situ hybridization, autoradiography or immunocytochemistry. After using the in vitro or in vivo transfection procedures high percentages $(80 \%)$ of spermatozoa appeared transfected (Spadafora; Huguet \& Esponda). These results usually showed that the foreign gene appeared into the nucleus of spermatozoa and molecular procedures (Slot-Blot, PCR, Southern Blot and gene sequences) have shown the presence of the transgene in the DNA of the gametes.

Gametes are protected against foreign gene entrance. The consequences of gamete transfection in nature would be dramatic. Nevertheless, gamete transfection has not been observed in nature. Then, it seems logical to assume that gametes must have some mechanism/s to block this phenomenon. In mammals only epididymal spermatozoa can be transfected and ejaculated gametes are refractory to transfection. In the mouse, Zani et al. (1995) showed that a 37 kDa semino plasma protein inhibit the DNA uptake. Similarly they founded that in the sea urchin sperm membrane occurred a similar protein with a similar function. Studies in the mouse also demonstrated that specific proteins from the seminal vesicle and the ventral prostate are capable to inhibit transfection (Carballada \& Esponda, 2001). Then in mammals, proteins of the seminal fluid seem to have a function in the blockage of transfection. Nevertheless, it is not known what occurs in species in which no accessory gland secretions exist as in birds or invertebrates.

In the case of the female gamete it seems clear that the oocyte envelopes like the zona pellucida (mammals) or the jelly coat (invertebrate eggs) are capable to inhibit transfection. Mouse oocytes (Carballada et al., 2000) and mollusks eggs (Guerra \& Esponda, 2005) with intact zona or jelly can not be transfected; but when these envelopes were removed transfection occurred in a large percentage of cells.

Transgenic production after gamete transfection. The employ of transfected gametes in order to produce transgenics have been issued using in vitro fertilization or inseminations. Several papers have show that transgenic animals were produced using these procedures and percentages of transgenics collected were sometimes high (Table I). Nevertheless, the employ of transfected gametes do not originate transgenic lines. Despite the results showed in Table I, no reports have appeared thereafter about the development of transgenic lines in these cases (Smith, 1999). The transgenic mice produced by transfected spermatozoa or oocytes demonstrated that they were chimeras (because the expression of the transgenes occurs only in some organs) (Carballada et al., 2002). Furthermore, they never produce a transgenic generation: a fact that cause several doubts about the fate of foreign genes in these animals.

Table I. Shows some cases of transgenic production using transfected spermatozoa.

\begin{tabular}{|c|c|c|c|c|}
\hline Class & Specie & Mode of Transfection $(*)$ & $\%$ of transgenic generated & Reference \\
\hline Molluscs & Abalone & Incubation & 65 & Tsai et al., 1997. \\
\hline \multirow[t]{2}{*}{ Fish } & Salmon & Electroporation & 85 & Symonds et al., 1994. \\
\hline & Zebrafish & Electroporation & 14 & Patil \& Khoo, 1996. \\
\hline Birds & Rooster & Lipofection & 25 & Rottmann et al., 1992. \\
\hline \multirow[t]{5}{*}{ Mammals } & Mouse & Incubation & 30 & Lavitrano et al., 1989. \\
\hline & & Incubation (in vivo) & 7.5 & Huguet \& Esponda, 2000. \\
\hline & Pig & Incubation & 5.7 & Sperandio et al., 1996. \\
\hline & & Incubation & 80 & Lavitrano et al., 2002. \\
\hline & Bovine & Incubation & 2.4 & Schellander et al., 1995. \\
\hline
\end{tabular}


Probably, transgenics generated by gamete transfection are different from those produced by the conventional procedure of gene injection. In the later, DNA integration clearly occurs in the host genome and transgenic lines are established. Something similar could occur in the case of transgenics generated by transfected death spermatozoa (Perry et al.). The real explanation about the origin of the transgenics produced by living transfected gametes remains as an enigma. It seems probable that various mechanisms that protect gametes (apart from those commented in 4) would occur. The living gamete nuclei would react in front to foreign gene integration, or would impede the integration of foreign gene into the germinal line. These protective mechanisms would be lost in death spermatozoa. New experiments are obviously required to answer these and several other questions.

Conclusions. In numerous vertebrate and invertebrate species the male and female gametes have been transfected using in vivo or in vitro conditions. Studies showed that a $60-80 \%$ of spermatozoa can be transfected, and that transgenes appeared principally localized into the nucleus of eggs and spermatozoa. These results are supported by molecular methodologies. Gametes appear protected from foreign gene entrance by semino plasma proteins in the case of the male, and by the egg envelopes (zona pellucida or jelly coats) in the female.

Several authors have shown in different species that transfected gametes originated transgenic animals. Nevertheless, this method for transgenesis did not originate transgenic lines and the animals produced are usually chimeras in which the germinal line is not transgenic. Surprisingly, transgenics and transgenic lines are originated when death spermatozoa incubated with gene constructions are microinjected into normal eggs. All these results indicate that the real fate of the transgenes in the host DNA of sperm or eggs is for the moment an enigma.

ESPONDA, P. Transfección de gametos: Un método para generar animales transgénicos. Int. J. Morphol., 23(3):281-284, 2005.

RESUMEN: Se comentan algunos aspectos sobre la transfección de gametos y su empleo para la producción de animales transgénicos (AT). Para la transfección de gametos han sido empleados ADN desnudo, vectores virales, complejos ADN-Liposomas, electroporación, o microproyectiles de alta velocidad. En general, se han obtenido altos porcentajes de transfección (hasta del $80 \%$ en espermatozoides) y se ha observado que los transgenes se localizan en el interior del núcleo. Se ha constatado que los gametos están naturalmente protegidos frente a la entrada de genes extraños: en espermatozoides esta función la cumplen diversas proteínas presentes en los fluidos seminales o en su membrana plasmática; mientras que en los gametos femeninos son las envolturas del huevo (zona pelúcida en mamíferos o membrana perivitelina en moluscos) las que desarrollan esta labor. En muchos casos, los gametos transfectados se han utilizado en fecundaciones in vitro o en inseminaciones a fin de crear AT. En algunos casos, los porcentajes de estos AT han sido altos, como en el salmón (85\%). Pero los AT, así creados, han sido en su mayoría quimeras y no han sido capaces de producir líneas transgénicas. Se sugiere que los AT producidos por gametos transfectados, son diferentes a los producidos por el método convencional de microinyección. Es probable que los gametos posean mecanismos, aún no descritos, capaces de modificar la integración/expresión de los transgenes, o que impedirían la integración de los transgenes en la línea germinal.

PALABRAS CLAVE: Oocito; Espermatozoide; Transfección; Animales transgénicos.

\section{REFERENCES}

Akasaka, K.; Nishimura, A.; Hijikata, K.; Iuchi, Y.; Takahashi, M.; Morika, H. \& Shimada, H. Introduction of DNA into sea urchin eggs by particle gun. Mol. Mar. Biotechnol., 4: 255-61, 1995.

Anderson, W. F. Human gene therapy. Nature., 392:25-30, 1998.

Arezzo, F. Sea urchin sperm as vector of foreign genetic information. Cell Biol. Int. Rep., 13:391-404.1989.

Brackett, B. G.; Baranska, W.; Sawicki, W. \& Koprowski, H. Uptake of heterologous genome by mammalian spermatozoa and its transfer to ova through fertilization. Proc. Natl. Acad. Sci. USA., 68:353-7, 1971.
Carballada, R.; Degefa, T. \& Esponda, P. Transfection of mouse eggs and embryos using DNA combined to cationic liposomes. Mol. Reprod. Dev., 56:360-5, 2000.

Carballada, R. \& Esponda, P. Regulation of foreign DNA uptake by mouse spermatozoa. Exp. Cell. Res., 262:104-13, 2001.

Carballada, R.; Relloso, M. \& Esponda, P. Generation of transgenic mice by transfection of pronuclear embryos using lipid-DNA complexes. Zygote., 10: 209-216, 2002.

Chan, A.W.; Chong, K.Y.; Martiniovich, C.; Simerly, C. \& Schatten, G. Transgenic monkeys produced by retroviral gene transfer into mature oocytes. Science., 291:309-12, 2001. 
Guerra, R. \& Esponda, P. Transfection of eggs in the bivalve mollusk Chamelea gallina using nakes DNA and DNA/ Liposome complexes. Animal Biotechnol. In press, 2005.

Huguet, E. \& Esponda, P. Foreign DNA introduced into the vas deferens is gained by mammalian spermatozoa. Mol. Reprod. Dev., 51:42-52, 1998.

Laurema, A.; Heikkila. A.; Keski-Nisula, L.; Heikura, T.; Letholainen, P.; Manninen, H.; Tuomisto, T.T.; Heinonen, S. \& Yla-Herttuala, S. Transfection of oocytes and other types of ovarian cells in rabbits after a direct injection into uterine arteries of adenovisuses and plasmid/liposomes. Gene Ther., $10: 580-4,2003$.

Lavitrano, M.L.; Camaioni, A.; Fazio, V.M.; Dolci, S.; Farace, M.G. $\&$ Spadafora, C. Sperm cells as vectors for introducing foreign DNA into eggs: genetic transformation in mice. Cell., 57:71723, 1989.

Lavitrano,M. L.; Bacci, M. L.; Forni, M.; Lazzereschi, D.; Di Stefano, C.; Fioretti, D.; Giancotti, P.; Marfe,G.; Pucci, L.; Renzi, L.; Wang, H.; Stoppacciaro, A.; Stassi, G.; Sargiacomo, M.; Sinibaldi, P.; Turchi, V.; Della Casa, G.; Seren, E \& Rossi, G. Efficient production by sperm-mediated gene transfer of human decay accelerating factor (hDAF) transgenic pigs for xenotransplantation. Proc. Natl. Acad. Sci. USA., 99:14230-5, 2002.

Lu, J. K.; Chen, T. T.; Allen, S. K.; Matsubara, T. \& Burns, J.C. Production of transgenic dwarf surfclams, Mulinia lateralis, with pantropic retroviral vectors. Proc. Natl. Acad. Sci. USA., 93:3482-6, 1996.

Mulligan R. C. The Basic science of gene therapy. Science, 249:1285-8,1993.

Patil, J. G. \& Khoo, H. W. Nuclear internalization of foreign DNA by zebrafish spermatozoa and its enhancement by electroporation. J. Exp. Zool., 274:121-9, 1996.

Perry, A. C.; Wakayama, T.; Kishikawa, H.; Kasai, T.; Okabe, M.; Toyoda, Y, \& Yanagimachi, R. Mammalian transgenesis by intracytoplasmic sperm injection. Science., 284:1180-3, 1999.

Powers, D.A.; Hereford, L.; Cole, T.; Chen, T.T.; Lin, C.M.; Kight, K.; Creech, K. \& Dunham, I. Electroporation: a method for transferring genes into the gametes of zebrafish (Brachydanio rerio), channel catfish (Ictalurus punctatus) and common carp (Cyprinus carpio). Mol. Mar. Biol. Biotechnol., 1:301-6, 1992.

Rottmann, O. J.; Antes, R.; Hoefer, P. \& Maierhof, G. Liposome mediated gene transfer via spermatozoa into avian egg cells. J. Anim Breed Genet., 109:64-70, 1992.

Schellander, K.; Peli, J.; Schmall, F. \& Brem, G. Artificial insemination in cattle with DNA-treated sperm. Anim Biotechnol., 6:41-50, 1995.
Smith, K.R. Sperm cell mediated transgenesis: a review. Anim. Biotech., 10: 1-13, 1999.

Spadafora, C. Sperm cells and foreign DNA: a controversial relation. BioEssays., 20:955-64, 1998.

Sperandio, S.; Lulli, V.; Bacci, M.L.; Forni, M.; Maione, B.; Spadafora, C. \& Lavitrano, M.L. Sperm-mediated gene transfer in bovine and swine species. Anim Biotechnol., 7: 59-77, 1996.

Symonds, J. E.; Walker, S. P.; Sin, F. Y. T. \& Sin, I. Development of a mass gene transfer method in Chinook salmon: optimization of gene transfer by electroporated sperm. Mol. Mar. Biol. Biotechnol., 3:104-11, 1994.

Szelei, J.; Varadi, L.; Muller, F.; Erdely, F.; Orban, L.; Horvath, L. \& Duda, E. Liposome-mediated gene transfer in fish embryos. Transgenic Res., 3:116-9, 1994.

Tsai, H. J.; Lai,C. H. \& Yang, H.S. Sperm as a carrier to introduce an exogenous DNA fragment into the oocyte of japanesse abalone (Haliotis diversicolor suportexta). Transgenic Research., 6:85-95,1997.

Tsukui, T.; Miyake, S.; Azuma, S.; Ichise, H.; Saito, I. \& Toyoda, Y. Gene transfer and expression in mouse preimplantation embryos by recombinant adenovirus vector. Mol. Reprod. Dev., 42:291-7, 1995.

Tsukui, T.; Kanegae, Y.; Saito, I. \& Toyoda, Y. Transgenesis by adenovirus-mediated gene transfer into mouse zona-free eggs. Nature Biotechnol., 14:982-5, 1996.

Wolff, J. A. \& Lederberg, J. An early history of gene transfer and therapy. Hum. Gene Ther., 5:469-80, 1994.

Zani, M.; Lavitrano, M.L.; French, D,; Lulli, V.; Maione, B.; Sperandio, S. \& Spadafora, C. The mechanism of binding of exogenous DNA to sperm cells: factors controlling the DNA uptake. Exp Cell Res:271:57-64, 1995.

Zelenin, A.V.; Alimov, A. A.; Barmintzev, V. A.; Beniumov, A.O.; Zelenina, I. A.; Krasnov, A. M. \& Kolesnikov, V. A., The delivery of foreign genes into fertilized fish eggs using highvelocity microprojectiles. FEBS. Lett., 287:118-20, 1991.

Correspondence to:

Dr. Pedro Esponda

Centro de Investigaciones Biológicas. CSIC.

Ramiro de Maeztu 9 (Lab $\mathcal{B}-08$ ).

28040 Madrid

SPAIN

Telephone: 34918373112

Fax: 34915360432

Email:esponda@cib.csic.es

Received: 14-04-2005

Accepted: 07-07-2005 